DOI: https://doi.org/10.35619/prap_rv.vi12.38

\title{
РЕФЛЕКСІЯ ЯК МЕХАНІЗМ ОСОБИСТІСНО-ПРОФЕСІЙНОГО СТАНОВЛЕННЯ МАЙБУТНІХ ВЧИТЕЛІВ
}

У статті аналізується значення рефлексї у проиесі професійної підготовки та особистіснопрофесійного становлення майбутніх вчителів. Рефлексія розглядається як невід'ємний компонент професійної майстерності педагога та основний психологічний механізм ефективної педагогічної взаємодії. Підкреслено роль рефлексії як особливого психічного процесу у регуляиії всіх компонентів діяльності вчителя - організаційного, комунікативного, конструктивного, гностичного, проектувального, які у своїи сукупності визначають ефективність виховних та розвивальних прочесів педагогічної взаємодї.

Ключові слова: рефлексія, рефлексивні уміння, вчитель, педагогічна діяльність, самопізнання, самоаналіз, професійна підготовка, професійне самовдосконалення.

В статье анализируется значение рефлексии в прочессе профессиональной подготовки и личностно-профессионального становления будущих учителей. Рефлексия рассматривается как неотъемлемый компонент профессионального мастерства педагога и основной психологический механизм эффективного педагогического взаимодействия. Подчеркнута роль рефлексии как особого психического прочесса в регуляиии всех компонентов деятельности учителя - организационного, коммуникативного, конструктивного, гностического, проектировочного, которые в своей совокупности определяют эффективность воспитательных $u$ развивающих прочессов педагогического взаимодействия.

Ключевые слова: рефлексия, рефлексивные умения, учитель, педагогическая деятельность, самопознание, самоанализ, профессиональная подготовка, профессиональное самосовершенствование.

Постановка проблеми. Трансформаційні процеси в сучасній освітній системі обумовлюють посилення уваги до пізнання людиною екзистенційних смислів власного внутрішнього світу, якості власної фахової діяльності через здійснення рефлексивних самопроцесів, зокрема самоаналіз, самооцінку й самокорекцію. Оволодіння рефлексивними діями дає змогу підготувати майбутніх вчителів до дистанціювання щодо свого «фахового Я» 3 метою усвідомлення особливостей сприймання себе як особистості та майбутнього фахівця. Значимість рефлексії у підготовці майбутніх вчителів посилюється тим, що їхня діяльність здійснюється у системі міжособистісних взаємин і визначається високим рівнем психоемоційного та смислового навантаження й напруження в процесі комунікації з учнями. Тому актуальність проблеми формування рефлексивних умінь майбутніх вчителів у процесі професійної підготовки посилюється необхідністю розв'язання певної суперечності: між вимогами гуманістичної освітньої парадигми щодо формування особистості, здатної до самоусвідомлення та орієнтованої на високі фахові досягнення як суб'єкта професійного розвитку завдяки потенціалу рефлексії у фаховому саморозвитку й самовдосконаленні та браком організаційно-методичного забезпечення рефлексивно-орієнтованого навчання щодо формування у студентів означених умінь у процесі професійної підготовки.

Формулювання цілей статті. Розкрити роль рефлексії у процесі професійної підготовки та особистісно-професійного вдосконалення майбутніх вчителів.

Результати теоретичного дослідження. У процесі еволюції філософської та психологічної думки поняття «рефлексія» як самостійна проблема розглядалася багатьма авторами та набула категоріального значення у структурі психіки людини в контексті дослідження процесів свідомості, самопізнання і пізнання особистості. Рефлексія була предметом наукової думки як способу пізнання ще за часів античної філософії (Сократ, Аристотель та ін.). Пізніше рефлексія пов'язувалась 3 усвідомленням пізнавальних актів, зверненням свідомості на себе (Дж. Локк, І. Кант, Г. Лейбніц, Г. Гегель та ін.). У психологічних дослідженнях рефлексія визначається як чинник самоусвідомлення, адаптації і творчого розвитку особистості (О. Алексєєв, О. Анісимов, В. Войтко, Н. Гуткіна, А. Зак, Н. Непомняща, І. Семенов, В. Слободчиков, С. Степанов та ін.). Психолого-педагогічні аспекти рефлексії як компонента професійної майстерності простежуються в дослідженнях І. Зязюна, Н. Гузій, Ю. Кулюткіна, І. Савенкової, Г. Сухобської та інших.

У галузі психологічної науки категорія «рефлексія» пов'язується з розумінням самоаналізу щодо осмислення закономірностей власного існування. Рефлексія дає змогу особистості на основі Випуск 12, 2019. Збірник наукових праць РДГУ 
усвідомлення парадигмальних засад пізнання переводити знання 3 неявної форми в явну, усвідомлену, формалізовану, що сприяє їхньої об’єктивізації. Рефлексія має на меті «методологічне обгрунтування теоретичної системи», а в якості результату виступає «збагачення ії об'єкта шляхом виявлення концептуальних структур більш високого порядку узагальнення» [12]. Систематичний науковий опис рефлексії в контексті еволюції психологічної науки розпочався у другій половині XX століття. Г. Щедровицький та В. Лефевр здійснювали аналіз дефініції «рефлексія» 3 точки зору методології мислення, виокремлюючи в якості основних два аспекти: рефлексія як структура діяльності, та рефлексія як принцип пізнання $[10 ; 16]$.

У сучасних психологічних дослідженнях рефлексія визначається як психічний процес, як психічний стан, як психічна властивість. При цьому, більшість джерел підкреслюють здатність рефлексії до об'єктивації свідомості, готовністю особистістю до самоаналізу та самодослідження, котрі спрямовані на збагачення внутрішнього знання особистості про себе, про свій внутрішній та оточуючий світ, забезпечують формування образу «Я» особистості, що $\epsilon$ шляхом до самовдосконалення. Рефлексивні процеси також пов'язуються 3 комунікативними процесами, зумовлюючи будування сприятливих особистісних взаємовідносин на основі чуйності, проникливості, толерантності, розуміння однією особистістю внутрішніх передумов вчинків та емоцій іншої особистості [7].

Сучасні дослідження рефлексії дають змогу узагальнити такі визначення рефлексії у дослідженнях свідомості та самосвідомості: 1) рефлексія як джерело самоперетворення на основі активного усвідомленого способу життя (М. Алексєєв, О. Огурцов, С. Рубінштейн, В. Слободчиков та ін.); 2) рефлексія як засіб пізнання світу і механізм продуктивного мислення (М. Алексєєв, С. Семенов та ін.); 3) рефлексія як механізм навчальної діяльності, розвитку свідомості (В. Давидов, В. Слободчиков, Г. Цукерман та ін.); 4) рефлексія як запорука переходу до опосередкованих форм поведінки і об'єктивізації з метою керування (Б. Зейгарник, В. Рубцов та ін.) [14].

Виклад основного матеріалу. Виокремлення певних сфер існування рефлексії як стану, як діяльності, як властивості в особистісному або культуротворчому контексті є досить умовним, адже всі контексти рефлексії мають свої проекції в філософських, психологічних, соціальних дослідженнях та знаходяться у взаємодії, що і зумовлює багатоаспектність та багатозначність визначення дефініції «рефлексія». Аналіз філософської, психологічної та педагогічної літератури з проблеми рефлексії дозволяє стверджувати, що рефлексія є полінауковою категорією, що визначається як психічний процес і синтетична розумова діяльність. Рефлексія у всій їі багатовимірності стає важливою психічною та діяльнісною складовою професійної майстерності у багатьох галузях. Особливо це стосується професій в системі «людина-людина», примітною ознакою яких $є$ насиченість психоемоційного фону, що ускладнює регламентацію діяльності. У цих умовах рефлексія, як здатність фахівця інтегрувати власний досвід, наявні теоретичні знання та дослідницький підхід 3 метою пошуку оптимального рішення неоднозначних практичних проблем, стає показником i проявом високого творчого потенціалу фахівця, продуктивності його інтелекту. Тому у контексті педагогічної діяльності рефлексія розкривається як невід'ємний компонент професійної майстерності педагога. Це зумовлено тим, що рефлексія $\epsilon$ джерелом пізнання власного внутрішнього світу, внутрішнього світу учнів, оточуючого середовища. Зважаючи на це, можна стверджувати, що рефлексія $\epsilon$ одним із основних психічних механізмів, котрий $\epsilon$ необхідним для педагога щодо організації педагогічної взаємодії, яка дозволяє на основі самодослідження регулювати власну діяльність та поведінку, i, одночасно, заглиблюючись у аналіз поведінки та мислення учнів, керувати їхньою діяльністю [2; 5].

Ю. Кулютнін та Г. Сухобська зазначають, що лише той педагог, який здатен зрозуміти інтереси, бажання, інтенції, психічні особливості учнів, буде спроможний, спираючись на картину внутрішнього світу учня, регулювати його поведінку, розвиваючи в нього особистісні механізми самодослідження та саморегуляції. 3 цим погоджується О. Лобок, який зазначає, що тільки на основі рефлексії педагог здатен побудувати ефективну суб'єкт-суб'єктну взаємодію з учнями. Автор у цьому контексті визначає рефлексію, як «особливу розумову операцію, що дозволяє здійснити своєрідне подвоєння свідомості 3 подальшою організацією своєрідного діалогу між двома утвореними суб'єктами» $[9,201]$.

Рефлексивність $\epsilon$ необхідною властивістю практичного мислення вчителя, мета якого полягає в застосуванні загальних знань у конкретних сиуаціях (Ю. Кулюткін, Г. Сухобская, Є. Осипова). Саме рефлексія стає опосередкованою ланкою між концептуальним апаратом фахівця та його особистісним досвідом. Без рефлексивного опрацювання професійні «предметні» знання, 3 яких складаються концептуальні уявлення, є «розсипаними» у свідомості (І. Семенов), що не дозволяє їм безпосередньо керувати діями. 3 іншого боку, недостатньо ефективним $\epsilon$ i досвід практичної 
діяльності, якщо він рефлексивно не осмислений, адже, як підкреслював К. Д. Ушинський, використовується не сам по собі досвід, а думка, виведена 3 нього. 3 приводу цього один 3 засновників рефлексивної педагогіки М. Уоллес писав, що рівень рефлексивних здібностей педагога зумовлює рівень якості його професійної діяльності, адже невідрефлексований досвід педагогічної практики веде не до розвитку, а, навпаки, до стагнації педагога [4]. Як бачимо, рефлексія є психічним процесом, який дозволяє регулювати всі компоненти діяльності вчителя - організаційний, комунікативний, конструктивний, гностичний, проектувальний. При цьому Л. Мітіна зазначає, що сама рефлексія входить до переліку професійних здібностей учителя. 3 цим погоджується I. Зимня, інтегруючи рефлексію у професійну свідомість педагога, однією зі специфічних рис якої дослідниця називає відповідальність за виховання інших людей [11]. Ю. Кулюткин наголошує на думці, що психічний процес педагогічної взаємодії з учнями пов'язується з рефлексивним управлінням їхньої діяльністю. Такий рефлексивний вплив має на меті формування активної суб'єктної рефлексивної позиції кожного учня, розвитку в нього здатності до саморегуляції [9].

Отже, рефлексія та рефлексивні процеси включені в усі компоненти педагогічної діяльності та визначають виховні та розвивальні процеси у контексті педагогічної взаємодії. Вчені наполягають на необхідності рефлексивного ставлення педагога до власної професійної діяльності, що зумовлено тим, що рефлексія дає змогу об’єктивації власного особистісного і професійного досвіду, та, одночасно, розуміння досвіду як передумови вчинків та мислення інших. Також підкреслюють важливість відходу від егоцентричності, формування толерантності вчителя, що $є$ його необхідною професійною якістю. I саме завдяки рефлексії педагог займає позиції об'єктивної оцінки себе та інших, зокрема учнів. Це дає змогу педагогу усвідомити неможливість «нав'язування» учням свого способу мислення, власних думок, адже це знижує ефективність всього педагогічно-виховного процесу. У цьому контексті рефлексивність для педагога $є$ джерелом самоаналізу, який $є$ необхідним чинником професійного самовдосконалення. Саме рефлексія дозволяє педагогу осмислювати i узагальнювати свої вчинки, думки, реакції, розумові процеси як в ретроспективній формі, так і в інтроспективній, та перспективній, з метою здійснення позитивних зрушень і наближення реального професійного образу до бажаного, ідеального «Я». До того ж рефлексія визначає комунікацію 3 учнями у педагогічному процесі, адже на основі рефлексивного осмислення вчитель усвідомлює доцільність власних педагогічних впливів, шукає шляхи вирішення педагогічних проблем, розуміє (через особистісні смисли) думки, реакції та вчинки учнів з метою підвищення толерантності та ефективності педагогічної взаємодії [9, 77-78].

А. Бізяєва підкреслює значимість рефлексії для педагогічної діяльності через іiі дослідницький, нерегламентований характер. Зокрема, процес гуманізації, що пронизує діяльність сучасної школи, вимагає підвищеної рефлексії свідомості у пізнанні людиною самої себе i підвищеного почуття відповідальності за іншу людину. Слід також зазначити, що педагогічну рефлексію (під якою розуміють співвіднесення себе, можливостей свого «Я», своєї діяльності з тим, чого вимагає обрана професія педагога, в тому числі, з існуючими про неї уявленнями) можна розглядати як загальну якість, оскільки кожна людина бере участь у педагогічній взаємодії, хоч і не завжди у професійному контексті [2].

Важливою особливістю педагогічної рефлексії є іï націленість на самоаналіз. Педагогічна рефлексія не може бути компенсована кимось ззовні. Тому роль рефлексії проявляється у забезпеченні критичного ставлення педагога до себе, що дозволяє глибоко та адекватно усвідомити свої недоліки, суб'єктивні труднощі, відсутність або недостатню розвиненість педагогічниї здібностей, вмінь та моральних якостей. Як відзначає І.С.Кон, будь-який процес управління вимагає відомостей, інформації про об'єкт управління $[8,282]$. Тому, коли мова йде про саморегуляцію, про самоуправління, то це вимагає інформації суб'єкта про самого себе. Повну та адекватну інформацію про власні якості та особливості педагог отримує в результаті самопізнання. Рефлексія, на відміну від самопізнання, дає відповіді не тільки на констатуючі питання (наприклад, «Що я знаю про себе?»), а й на причинні (наприклад, «Чому я вчинив саме так?»). Тому саме рефлексія забезпечує регулюючу функцію образу «Я» у професійній діяльності вчителя.

Образ «Я» педагога як результат самопізнання виступає основою для реалізації оціночного ставлення до себе, або самооцінки. Самооцінка включена в структуру саморегуляції поведінки як підстава для встановлення цілей педагогічної діяльності. В численних дослідженнях, присвячених самооцінці, стверджується, що позитивна оцінка себе та своїх можливостей є запорукою успіху у професійній діяльності (К.Роджерс, А.Маслоу, К.Хорні та ін.), а позитивне ставлення до себе корелює $з$ доброзичливим ставленням до інших. Самооцінка містить як когнітивні, так і емоційнооцінні елементи. Як доведено у дослідженні М.Й. Боришевського, обгрунтована реалістична самооцінка, яка спирається на усвідомлені дані про себе, має позитивний вплив на саморегуляцію 
поведінки [3, 26]. Розвиток самооцінки на основі усвідомлення себе, логічних розмірковувань та суджень про себе можливий завдяки здатності до рефлексії, яка дозволяє подивитись на себе з різних точок зору, абстрагуючись від несуттєвого. Саме реалістичність та обгрунтованість самооцінки мають вирішальне значення для саморегуляції поведінки під час професійної діяльності педагога. В цьому випадку головним є не піднесення власної значущості, не власна задоволеність, а усвідомлення переваг свого становища, що проявляється у почутті поваги до інших суб'єктів педагогічної взаємодії. Самоповага та почуття власної гідності у професійній діяльності вчителя пов'язані з оцінкою своїх педагогічних здібностей та можливостей як таких, що допомагають вчителю долати власні вади та об’єктивні перешкоди задля досягнення цілей навчання і виховання.

Крім того, оцінка педагогом своїх здібностей та можливостей проявляється у рівні домагань, у здатності поставити перед собою таку мету діяльності та поведінки, яка найбільше відповідає його можливостям та професійній майстерності. Рефлексія у встановленні рівня домагань виконує функцію оцінки обставин та ситуацій навчання і виховання, що складаються і реальних можливостей суб'єкта, що навчається. Це дозволяє скоректувати поставлені цілі навчання і виховання, уточнити завдання та умови їх реалізації.

Відсутність або недостатня сформованість педагогічної рефлексії робить педагога залежним від зовнішніх факторів - стимулів, обставин, впливів, котрі перетворюють його у виконавця чужої волі, а його діяльність перетворюється на процедуру «псевдодіяльності». Рефлексія не потребує насильницького впливу, адже за природою самостійна. Рефлексія сприяє тому, що свобода набуває характеру необхідності, а суб'єкт відчуває потребу зрозуміти себе в ситуації, зрозуміти, що відбувається в ньому протягом ситуації. Тому навчання майбутнього педагога рефлексії - це найважливіший засіб формування культури професійної діяльності і культури мислення педагога, шлях реалізації гуманістичної парадигми освіти [2].

Значення самоаналізу, який $є$ механізмом рефлексії, у якості засобу вдосконалення педагогічного процесу відображено в дослідженнях багатьох вчених (Ю. Бабанський, Н. Горбунова, Д. Іорданова, О. Орлов, Л. Плескач, К. Сергієва, І. Шамрай та інші). Самоаналіз в діяльності педагога забезпечую можливість, в тому числі в процесі фахової підготовки, адаптуватися до умов роботи, яка нерідко характеризується як непередбачувана, діагностувати власну діяльність на предмет проблем і рис, які потребують вдосконалення. 3 огляду на це, педагогічний самоаналіз є невід'ємним компонентом професійної майстерності вчителя [15]. Також варто відзначити роль самоаналізу в контексті осмислення педагогом власного особистісно-професійного досвіду. Важливим аспектом використання власного досвіду в професійній діяльності є наявність осмислених, усвідомлених схем, моделей та алгоритмів, побудованих на основі цього досвіду. Ці схеми і алгоритми інтегруються у свідомість фахівця в якості певних шаблонів, шляхів вирішення проблем тощо. Прицьому найефективнішим $\epsilon$ саме проаналізований, відрефлексований та засвоєний на вищому рівні досвід, який є невід'ємним компонентом професійної майстерності. Саме наявність у фаховій підготовці вчителя готовності до самоаналізу дозволяє вивчати, адекватно оцінювати і коригувати власну діяльність, орієнтуючись на актуальні професійні завдання; виявляти свої сильні і слабкі сторони, визначати шляхи професійного удосконалення.

Таким чином рефлексія $є$ одним із механізмів саморозвитку та самовдосконалення особистості. На шляху самовдосконалення рефлексивні дії дають змогу особистості актуалізувати процеси самоорганізації, мобілізуючи власний потенціал, інтелектуальні та духовні ресурси в умовах професійної діяльності. Осмислення образів, з якими ідентифікує себе особистість (реального «Я» та «Я»-ідеального) формує особистісні смисли та поступово породжує новоутворення, які змінюють особистість та передумови її діяльності. В такому ракурсі рефлексія виступає в якості найважливішої професійно-значущої якості особистості вчителя, котра визначає рівень його професійної придатності. У цьому сенсі рефлексія виступає, як здатність фахівця прогнозувати, програвати в розумі і адекватно оцінювати як можливі, так і реальні результати вжитих ним дій стосовно відношення до самих різних аспектів своєї діяльності - навчальної, діагностичної, виховної тощо. Рефлексію також можна розглядати як компонент соціальноперцептивних здібностей педагога, які забезпечують процес адекватного сприйняття вчителем своїх учнів, і через них - у дзеркальному відображенні - самого себе (Е. Альошина, С. Кондратьєва, В. Кривошея, Н. Кузьміна, Т. Яценко); як необхідну сторону комунікативного мистецтва вчителя (А. Леонтьєв, А. Маркова, С. Робертсон); як фактор, що визначає ефективність прогностичних умінь вчителя (Л. Регуш, Е. Бланк).

Рефлексія забезпечує можливість вчителю глибокого аналізу ситуації спілкування, обгрунтування мотивації вчинків партнерів по педагогічній взаємодії, встановлення та регулювання однакових моральних вимог щодо себе та інших, що в кінцевому результаті дозволить учням впевнено почувати себе в світі, зміцнити своє «Я» та виховати в собі витримку, волю, організованість 
тощо. Вчителю 3 розвиненою рефлексією властиві прагнення до самовдосконалення, почуття відповідальності за благополуччя інших людей. Таким чином, у процесі професійної діяльності педагога рефлексія забезпечує функціонування усіх складових системи саморегуляції його професійної діяльності: цінностей, образу Я та самооцінки, рівня домагань та самоконтролю. В ситуаціях педагогічної взаємодії рефлексія є не стільки зосередженням на собі, скільки засобом пізнання та об'єктивації образу учня, який сприймається як цілісна особистість. Тобто суб'єктсуб'єктні відносини у педагогічній площині передбачають психологічну єдність партнерів, у якій розгортається їх творче взаємозбагачення. Такі відносини передбачають емоційну й особистісну відкритість партнерів, психологічний настрій на актуальний стан один одного, щирість, довір'я i безпосередність у вияві почуттів та душевних станів. Отож необхідною умовою суб'єктного сприймання іншої людини є наявність розвинутої рефлексії . Вона дозволяє не тільки вчителю, а й учню відчувати себе суб'єктом власної активності, волі, переживань. Власне «Я» при цьому виступає як унікальне, а це робить можливим таке ж сприймання іншого як унікальної особистості.

Другим важливим завданням рефлексії є іï здатність зробити власне «Я» об’єктом власного дослідження та управління. Так формуються уявлення педагога про свої моральні якості, можливості, ïx оцінка та значущість. Учень при цьому також постає як об'єкт, оскільки пізнання якостей іншого та їх порівняння зі своїми дозволяє вчителю переосмислювати й перебудовувати власну професійну діяльність, ціннісні орієнтації, способи практичної діяльності, а також і себе як носія професійноособистісні властивостей, цінностей та установок.

Висновки 3 даного дослідження. Отже, як можемо бачити, рефлексія - це складне явище, яке розглядається у якості психічного механізму, стану, філософського мислення, яке інтегрує всі психічні функції людини з метою гармонізації її життєдіяльності, вирішення проблемних ситуацій, подолання перешкод (зовнішніх та внутрішніх) та самовдосконалення особистості. Можна стверджувати, що надзвичайно важливою рефлексія визнається в дослідженні теоретичних та методологічних засад діяльності вчителя. В означеному контексті рефлексія знаходить відображення у багатьох аспектах. Різні прояви рефлексії наповнюють всі види професійної діяльності педагога, його фахову психограму. Рефлексія визначає педагогічну діяльність і в контексті педагогічної взаємодії з учнями та студентами, і в процесі нормування та керування власною професійною діяльністю, і в процесі аутовзаємодії - тобто, розуміння себе, своїх професійних інтенцій, уявлень про власний професійний образ тощо.

Таким чином рефлексія - це шлях до усвідомлення та активізації власного особистіснопрофесійного досвіду, умова формування внутрішніх смислів і будування на їхньої основі ефективної педагогічної комунікації, заснованої на принципах суб'єктивності та свободи. Саме рефлексія, на основі самодослідження та самоаналізу дає змогу вчителю, як в процесі фахової підготовки, так і в процесі здійснення професійної діяльності, усвідомлюючи себе як суб'єкта педагогічної взаємодії, планувати свій індивідуальних шлях, власну траєкторію професійного самовдосконалення.

\section{Список використаних джерел}

1. Анисимов О. С. Рефлексивные основы самопознания / О. С. Анисимов // Мир психологи. 2016. - № 3 (87). - С. 84-96.

2. Бизяева А. А. Психология думающего учителя: педагогическая рефлексия / А. А. Бизяева. Псков : ПГПИ им. С. Кирова, 2004. -216 с.

3. Боришевський М. Й. Психологічні механізми розвитку особистості / М. Й. Боришевський // Педагогіка і психологія. - 1996. - № 3. - С. 26-33.

4. Вульфов В. 3. Педагогика рефлексии / В. 3. Вульфов, В. Н. Харькин. - Москва, 1995. - 112 c.

5. Галузяк В. М. Розвиток рефлексивності у майбутніх учителів / В. М. Галузяк // Розвиток професійно важливих якостей у майбутніх учителів : монографія / О. В. Акімова, В.М.Галузяк, О. В. Волошина та ін. - Вінниця : ТОВ «Нілан-ЛТД», 2016. - 248 с.

6. Зимняя И. А. Педагогическая психология : учеб. для вузов / И. А. Зимняя. - Москва : Логос, 2000. $-383 \mathrm{c}$.

7. Карпов А. В. Психология рефлексивных механизмов управления / А. В. Карпов, В. В. Пономарева. - Москва, 2000. - 323 с.

8. Кон И. С. Открытие «Я» / И. С. Кон. - Москва: Политиздат, 1978. - 367 с.

9. Кулюткин Ю. Н. Исследование познавательной деятельности учащихся / Ю. Н. Кулюткин, Г. С. Сухобская. - М. : Педагогика, 1999. - 151 с.

10. Лефевр В. А. Рефлексия / В. А. Лефевр. - Москва: Когито-Центр, 2003. - 496 с. 
11. Митина Л. М. Психология труда и профессионального развития учителя / Л. М. Митина. - Москва: Логос, 2004. - 320 с.

12. Психологічний словник / ред. В. І. Войтка. - Київ : Вища шк., 1982. -215 с.

13. Слободчиков В. И. Психологические условия введения студентов в профессию педагога / В. И. Слободчиков, Н. А. Исаева // Вопросы психологии. - 1996. - № 4. - С. 17-26.

14. Феноменологія морального розвитку особистості: детермінація, механізми, генезис : монографія / під ред. : Р. В. Павелківа, Н. В. Корчакової. - Рівне, 2009. - 368 с.

15. Шамрай І. Ю. Самоаналіз як педагогічна проблема / І. Ю. Шамрай // Педагогічна освіта: теорія і практика. - 2011. - Вип. 9. - С. 73-77.

16. Щедровицкий Г. П. Мышление. Понимание. Рефлексия / Г. П. Щедровицкий. - Москва, 2005. -800 c.

\section{References}

1. Anisimov O. S. Refleksivnyye osnovy samopoznaniya / O. S. Anisimov // Mir psikhologi. - 2016. - № 3 (87). - S. 84-96.

2.Bizyayeva A. A. Psikhologiya dumayushchego uchitelya: pedagogicheskaya refleksiya / A. A. Bizyayeva. - Pskov : PGPI im. S. Kirova, 2004. - $216 \mathrm{~s}$.

3. Boryshevs'kyy M. Y. Psykholohichni mekhanizmy rozvytku osobystosti / M. Y. Boryshevs'kyy // Pedahohika i psykholohiya. - 1996. - № 3. - S. 26-33.

4. Vul'fov V. Z. Pedahohyka refleksyy / V. Z. Vul'fov, V. N. Khar'kyn. - M., 1995. - 112 s.

5. Haluzyak V. M. Rozvytok refleksyvnosti u maybutnikh uchyteliv / V. M. Haluzyak // Rozvytok profesiyno vazhlyvykh yakostey u maybutnikh uchyteliv : monohrafiya / O. V. Akimova, V. M. Haluzyak, O. V. Voloshyna ta in. - Vinnytsya : TOV «Nilan-LTD», 2016. - $248 \mathrm{~s}$.

6.Zimnyaya I. A. Pedagogicheskaya psikhologiya : ucheb. dlya vuzov / I. A. Zimnyaya. - M. : Logos, 2000. - $383 \mathrm{~s}$.

7. Karpov A. V. Psikhologiya refleksivnykh mekhanizmov upravleniya / A. V. Karpov, V. V. Ponomareva. - M., 2000. - 323 s.

8. Kon I. S. Otkrytiye «YA» / I. S. Kon. - M. : Politizdat, 1978. - 367 s.

9. Kulyutkin Yu. N. Issledovaniye poznavatel'noy deyatel'nosti uchashchikhsya / Yu. N. Kulyutkin, G. S. Sukhobskaya. - M. : Pedagogika, 1999. - $151 \mathrm{s.}$

10. Lefevr V. A. Refleksiya / V. A. Lefevr. - M. : Kogito-Tsentr, 2003. - 496 s.

11. Mitina L. M. Psikhologiya truda i professional'nogo razvitiya uchitelya / L. M. Mitina. - M. : Logos, 2004. $-320 \mathrm{~s}$.

12. Psykholohichnyy slovnyk / red. V. I. Voytka. - Kyyiv : Vyshcha shk., 1982. - $215 \mathrm{~s}$.

13. Slobodchikov V. I. Psikhologicheskiye usloviya vvedeniya studentov v professiyu pedagoga / V. I. Slobodchikov, N. A. Isayeva // Voprosy psikhologii. - 1996. - № 4. - S. 17-26.

14. Fenomenolohiya moral'noho rozvytku osobystosti: determinatsiya, mekhanizmy, henezys : monohrafiya / pid red. : R. V. Pavelkiva, N. V. Korchakovoyi. - Rivne, 2009. - 368 s.

15. Shamray I. Yu. Samoanaliz yak pedahohichna problema / I. Yu. Shamray // Pedahohichna osvita: teoriya i praktyka. - 2011. - Vyp. 9. - S. 73-77.

16. Shchedrovitskiy G. P. Myshleniye. Ponimaniye. Refleksiya / G. P. Shchedrovitskiy. - M., 2005. $-800 \mathrm{~s}$.

\section{Teachers}

R. V. Pavelkiv Reflection as a Mechanism for the Personal and Professional Formation of Future

The article deals with the problem of formation of reflexive abilities of future teachers during the professional training. The significance and potential of reflection in professional self-development and self-improvement of future specialists, who are focused on high professional achievements, are substantiated. In the context of pedagogical activity, reflection provides teachers with an opportunity to assess their own pedagogical abilities and opportunities that help to overcome their own weaknesses and objective barriers in order to achieve the goals of education and upbringing. It is established that reflection is one of the mechanisms of self-development and self-improvement of the personality of the future teacher. On the path to self-improvement, reflexive processes enable an individual to actualize the processes of self-organization, to mobilize their own potential, intellectual and spiritual resources in terms of professional activity. It is noted that reflection is the most important quality of the teacher's personality from the professional point of view, which determines the level of his/her professional suitability. It is stated that during the professional activity of the teacher, reflection ensures the functioning of all components of the system of self-regulation of his or her professional activities: values, 
self image, level of aspiration and self-control. In situations of pedagogical interaction, reflection is not merely a focus on self, but a means of knowing and objectifying the image of a student, which is perceived as a holistic personality.

Key words: reflection, reflexive skills, teacher, pedagogical activity, self-knowledge, selfexamination, professional training, professional self-improvement.

УДК 316.61-053

O. I. APTEMOBA

DOI: https://doi.org/10.35619/prap rv.vi12.39

\section{СОЦАЛЬНО-ПСИХОЛОГІЧНІ ЧИННИКИ ВХОДЖЕННЯ МОЛОДІ У СУБКУЛЬТУРНИЙ ПРОСТІР}

У статті здійснено теоретичний аналіз сочіально-психологічних чинників входження молоді y субкультурний простір, впливу молодіжних субкультур на формування особистості, наголошується на необхідності розробки $і$ впровадження програм сочіалізаиіі молоді, в яких враховувавався б вилив субкультурного простору.

Ключові слова: молодіжна субкультура, субкультурний простір, девіантна поведінка, сочіально-психологічні чинники.

В статье осуществлен теоретический анализ социально-психологических факторов вхождения молодежи в субкультурное пространство, влияния молодежных субкультур на формирование личности, акцентируется внимание на необходимости разработки и внедрения программ сочиализачии молодежи, в которых учитывалось бы влияние субкультурного пространства.

Ключевые слова: молодежная субкультура, субкультурное пространство, девиантное поведение, сочиально-психологические факторы.

Постановка проблеми. Молодь $є$ рушійною силою розвитку суспільства, іiі стратегічним ресурсом, одним із визначальних чинників громадсько-політичного та соціально-економічного життя країни. 3 іншої сторони, молоді люди, які не сформували в собі систему цінностей, мають нестійкий світогляд, дуже часто піддаються впливам, знецінюють ідеали, не можуть знайти свого місця в житті, свою адекватну соціальну групу, реалізувати себе, а тому знаходять вирішення своїх проблем в молодіжних субкультурах. Молодіжна субкультура - це певне поле реалізації, що виникає як потреба у молодих людей, яке вони обирають при відсутності альтернативи. Тому дуже важливо вивчення різних молодіжних субкультур з метою визначення ефективного комплексу заходів профілактики девіантної та делінкветної поведінки молодих людей в неформальних об'єднаннях. Це дає підстави вченим посилити дослідження соціально-психологічних чинників входження молоді у субкультурний простір і активізувати пошуки ефективних шляхів попередження і подолання негативних проявів у молодіжному середовищі.

Аналіз останніх досліджень і публікацій. Увага вчених до проблеми молодіжних субкультур та їх впливу на розвиток особистості інтенсифікувалася з середини 80 -х років минулого століття, коли послабився загальний ідеологічний тиск, почали руйнуватися старі організаційні форми i молодь отримала можливість більш вільно заявляти про свої уподобання, обирати форми особистісного самовияву. Проблемі впливу молодіжних субкультур на формування особистості присвячені дослідження багатьох сучасних вітчизняних i зарубіжних психологів, зокрема Л. С. Алексеєва, І. П. Башкатова, М. О. Белашова, С.А.Бєлічева, В.Г. Бочарова, Л. П. Буєва, Ю.В. Грищук, В. Г. Деєва, Л. Д. Заграй, І. С. Кона, Т.В. Кравченко, Н.Ф Кузнецова, Ю.О. Лисенко, Ю. М. Мельника, В. І. Мироненко, В. Р. Павелківа, Б.Д. Паригіна, О. С. Товканець, А.М. Яковлева та ін. Особливо увага акцентується на психолого-педагогічних особливостях учасників молодіжних об'єднань, їх протидія існуючій системі, анархії, несправедливості.

Актуальними на сьогоднішній день залишаються питання асоціальної поведінки молоді. Теоретико-методологічні дослідження в цьому напрямі представлені роботами А. Адлера, Ю. К. Александрова, Ю.М.Антоняна, О. Бандури, А.Басса, І.П.Башкатова, З. Берковіц, Дж. Брауна, Ф.Д.Кадарія, П. Кауфман, Ю.В. Лазарєва, С.Я.Лебедєва, К. Левіна, К. Лоренца, М.Мюррей, А.В.Петряніна, В.Ф. Пирожкова, К. Річарда, Р.Уолтера, 3. Фрейда, Е. Фромма, І.О. Фурманова, М. В. Шакурової та ін. В основному вони висвітлювали питання становлення та діяльність підліткових субкультур, вплив субкультур на формування особистості в підлітковому віці, 